\title{
Agrobiological basis of wheat yield formation Dicoccum Schrank (spelt) in the ancestral domain of the Republic of Tatarstan
}

\author{
Farit Shaikhutdinov, Igor Serzhanov*, Albina Serzhanova, Abdulsamat Valiev, and Venera Aksakova \\ Kazan State Agrarian University, Kazan 420015, Russia
}

\begin{abstract}
The article presents the results of a three-year (2016-2018) study on the role of seeding rates taking into account the depth of seeding on different backgrounds of mineral nutrition in the conditions of gray forest soils in the middle Volga region. Experiments were conducted on the pilot field of the Department of Plant Industry and Horticulture of Kazan State Automobile University. Soil of the experimental site is characterized by the following agrochemical indicators: humus content $-2.9-3.2 \%$ (according to Tyurin), the sum of the absorbed bases $-27 \mathrm{mg}$.-per $100 \mathrm{~g}$ of soil, light hydrolysable nitrogen $-79.0 \ldots 110 \mathrm{mg} / 1000 \mathrm{~g}$ (according to Corinth), mobile phosphorus and potassium (according to Kirsanov) $105 \ldots 184$ and $79 \ldots 149 \mathrm{mg} / 1000 \mathrm{~g}$ of soil, pHsol.- 5.6-5.7. Research material - double-grain wheat Triticum Dicoccum Schrank (spelt) grade Runo. During all the years of research, the soil layer 4 and $6 \mathrm{~cm}$ was the most wetted during the sprouting phase. On average, for 3 years the best completeness of sprouting was provided by sowing rates of $4-5$ million germplasm seeds per hectare at the depth of seed placement by 2 and $4 \mathrm{~cm}$. Safety of plants to full ripeness at sowing of 6 million grains per hectare on both feeding backgrounds made up at planting of seeds on $2 \mathrm{~cm}-414-423$ pieces $/ \mathrm{m}^{2}, 4 \mathrm{~cm}-411-432$ and $6 \mathrm{~cm}-$ 356-374 plants on $1 \mathrm{~m}^{2}$. The highest yield for 3 years on average on both feeding grounds $(1.93 \ldots 2.55 \mathrm{t} / \mathrm{ha})$ was provided by sowing 4 million grains per hectare when planting seeds by $4 \mathrm{~cm}$.
\end{abstract}

\section{Introduction}

Achieving guaranteed and stable annual yields of high quality spring wheat grain with the lowest cost of funds and labor resources is possible with the development of innovative technologies. One of the promising directions is the use of complex fertilizers with microelements in chelate form, growth regulators and bacterial preparations, which allow to form highly productive crops in local natural-climatic conditions $[1,2]$.

Optimal depth of seed placement depends on the mechanical composition, structure, moisture of the upper layer of soil, the size of seeds. Shallower embedding is required on non-structured soils of heavy mechanical composition (clayey), shallower embedding is required on light (sandy loam) structural soils, shallower embedding on wet weather in spring, and deeper embedding of coarse seeds in dry, windy years; coarse seeds can be placed deeper than shallow ones [3, 4].

On the experimental fields of Kazan State Automobile Inspection Agency, when comparing the depth of seed placement by $2,4,6 \mathrm{~cm}$, the best yield for two years on average was obtained when planting by $4 \mathrm{~cm}$. [5, 6].

Both too deep and too shallow seed placement are equally undesirable. At deep sowing the shoots are delayed for 1-2 days, they are weakened, they are more suppressed by weeds; at shallow sowing many seeds do not give sprouting because of soil drying up, plants are weakly rooted, lie down more $[7,8]$.
The value of seed depositing depth is not limited only by the influence on the field germination. It affects the structure of the plant as a whole, the structure and the size of the yield per unit area [9].

In the system of agrotechnical methods aimed at obtaining high and stable yields of spring wheat, an important value belongs to the norms of sowing seeds. Both in case of thin crops (due to insufficient use of the allotted area) and in case of excessively dense crops (due to lack of moisture and nutrients, as well as due to lodging) the yield decreases $[10,11]$.

\section{Materials and methods}

The object of the research was half a dozen Runo's wheat. Experiments were conducted in 2016-2018 on gray forest soil in the Predkamsk zone of the Republic of Tatarstan. The content of humus in the layer of $0-20 \mathrm{~cm}-2.9-3.2 \%$ (according to Tyurin) of mobile phosphorus 170-176 mg, exchangeable potassium - 108-110 mg/kg of soil (according to Kirsanov), the sum of absorbed bases $-26 \mathrm{mg}$ per $100 \mathrm{~g}$ of soil. The degree of saturation of bases $-85.2 \%, \mathrm{pH}$ of salt extract - 5.6. Experiments were carried out according to the following scheme: seed placement at the depth of 2, 4 and $6 \mathrm{~cm}$ at sowing rates of 4, 5, 6 and 7 million germinated grains per hectare and at two levels of nutrition: 1 - natural background; 2 - estimated background for the planned level of grain

Corresponding author: igor.serzhanov@ mail.ru 
yield of 3 tons per 1 hectare. Repetition of experience four times, the location of plots - one-tier, rented. The total area of the plots is $60 \mathrm{~m}^{2}$, the registration area is 50 $\mathrm{m}^{2}$.

Predecessor - winter rye after pure steam. Treatment of zyabas with preliminary stubble removal was carried out in the third decade of August. Fertilizers were calculated using the calculation and balance method and applied for pre-sowing cultivation in doses: N16-55P1920K6-9. Sowing was carried out after pre-sowing cultivation in the first days of sowing spring cereals: seeds of the first class, the sowing machine $\mathrm{CH}-16$, on MTZ-80 tractor. Sowing care was carried out in accordance with the requirements of progressive technology of spring wheat cultivation. Testing was carried out in the phase of full maturity by SAMPO-500 combine harvester.

\section{Results}

Meteorological conditions in 2016 were characterized by insufficient moisture and an increased temperature regime during the initial periods of vegetation. High average daily air temperatures in the first and third tenday periods of May - deviation from the mean annual norm $\left(+2.4\right.$ and $\left.+2.9{ }^{\circ} \mathrm{C}\right)$ in combination with uneven precipitation (in the first ten-day period $-3 \mathrm{~mm}$, II $8 \mathrm{~mm}$, III - without precipitation) $-28.3 \%$ of the norm, had a negative impact on the yield. Conditions in 2017 were unfavourable for the appearance of sprouting. May and June were cool and humid - the average daily air temperature in May was $1.1{ }^{\circ} \mathrm{C}$ below the multiyear average and in June $-1.3{ }^{\circ} \mathrm{C}$ below the multiyear average. Insufficient heat regime after all sowing dates prolonged sprouting (sprouting dates I - 20 days, II 16 days and III - 13 days). In May, $32.1 \mathrm{~mm}$ or $11.7 \%$ of the norm was observed, in July $-93.1 \mathrm{~mm}$ or $157.8 \%$ of the norm.

Spring 2018 was dry - in May $21.8 \mathrm{~mm}$ of precipitation, or $55.9 \%$ of the norm, in June $-34.4 \mathrm{~mm}$, or $60.7 \%$, in the second half of July - the norm (52 mm).

Soil moisture at the seed placement depth on the sowing day was almost the same in all variants. In the following periods, the water regime of the studied soil layers developed differently. In the sprouting phase, the soil layer with the highest moisture content was 4 and $6 \mathrm{~cm}$. Later on, the higher the soil moisture was, the deeper the seeds were planted.

Formation of spelt wheat stem depended on the norms of sowing and seed depositing depth on all feeding backgrounds. On average, for three years the highest completeness of sprouting was provided by the lowered norms of seeding at the depth of seeding by 2 and $4 \mathrm{~cm}$.

On all variants with increasing the depth of seeding and seeding rates, regardless of the level of nutrition, the completeness of sprouting decreased. Thus, the field germination on both feeding backgrounds when planting seeds by $2 \mathrm{~cm}$ was 4 million 82.0-85.4\%, 7 million 76.7-76.9\%. A similar picture was formed when planting seeds at a depth of 4 and $6 \mathrm{~cm}$.
In addition, during the growing season there was a significant dropout of plants from spelt wheat agrocenosis. Biological resistance of plants to treason, sowing rates and nutrition background. On average, for 3 years the number of fallen out plants in the period from sprouting to full ripeness was higher when planting seeds at a depth of $6 \mathrm{~cm}$. For example, when sowing 6 million grains per hectare on both feeding grounds from sprouting to full ripeness remained when planting seeds at $2 \mathrm{~cm}-414-423 \mathrm{pcs} / \mathrm{m}^{2}, 4 \mathrm{~cm}-411-432 \mathrm{pcs} / \mathrm{m}^{2}$ and $6 \mathrm{~cm}-356-374$ plants per square meter, which amounted to 356-374 plants, respectively, in relation to sown seeds: 69.0-70.5, 68.5-2.0 and 59.3-62.3\% (Table 1).

Features of growth and development conditions of plants, formed in accordance with the meteorological indicators of the growing season at different depth of seed placement depending on seeding rates and nutrition levels, determined the yield of spelt wheat (Table 1).

Table 1. Yield and quality of Runo double-grain (spelt) wheat grains depending on the background of nutrition, seed placement depth and sowing rate (average for 2016-2018)

\begin{tabular}{|c|c|c|c|c|c|c|c|c|}
\hline 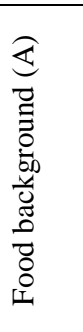 & 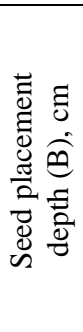 & 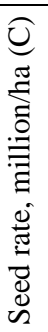 & 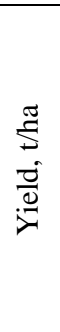 &  & 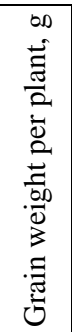 & 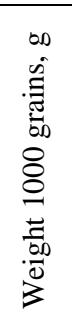 & 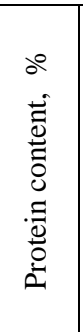 & 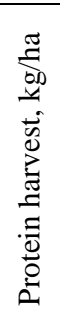 \\
\hline \multirow{12}{*}{ 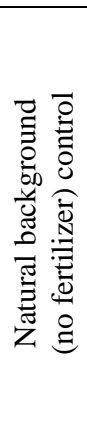 } & \multirow[t]{4}{*}{2} & 4 & 1.75 & 302 & 0.59 & 33.7 & 15.25 & 267 \\
\hline & & 5 & 1.73 & 353 & 0.52 & 33.4 & 15.31 & 265 \\
\hline & & 6 & 1.66 & 414 & 0.48 & 33.0 & 15.35 & 255 \\
\hline & & 7 & 1.62 & 439 & 0.43 & 32.7 & 15.33 & 248 \\
\hline & \multirow[t]{4}{*}{4} & 4 & 1.93 & 307 & 0.65 & 34.1 & 15.27 & 295 \\
\hline & & 5 & 1.87 & 354 & 0.57 & 33.8 & 15.33 & 287 \\
\hline & & 6 & 1.84 & 411 & 0.52 & 33.4 & 15.38 & 283 \\
\hline & & 7 & 1.73 & 437 & 0.50 & 33.0 & 15.34 & 265 \\
\hline & \multirow[t]{4}{*}{6} & 4 & 1.78 & 276 & 0.65 & 34.0 & 15.18 & 270 \\
\hline & & 5 & 1.57 & 323 & 0.51 & 33.6 & 15.21 & 239 \\
\hline & & 6 & 1.52 & 356 & 0.49 & 33.1 & 15.30 & 233 \\
\hline & & 7 & 1.47 & 404 & 0.41 & 32.6 & 15.26 & 224 \\
\hline \multirow{12}{*}{ 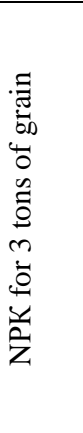 } & \multirow[t]{4}{*}{2} & 4 & 2.14 & 309 & 0.72 & 35.6 & 20.0 & 428 \\
\hline & & 5 & 2.06 & 364 & 0.65 & 35.0 & 20.10 & 414 \\
\hline & & 6 & 2.00 & 423 & 0.56 & 34.7 & 20.10 & 402 \\
\hline & & 7 & 1.95 & 448 & 0.52 & 34.1 & 20.13 & 393 \\
\hline & \multirow[t]{4}{*}{4} & 4 & 2.55 & 315 & 0.83 & 35.9 & 20.18 & 515 \\
\hline & & 5 & 2.34 & 372 & 0.71 & 35.3 & 20.14 & 471 \\
\hline & & 6 & 2.41 & 432 & 0.64 & 35.0 & 20.21 & 487 \\
\hline & & 7 & 2.19 & 460 & 0.56 & 34.7 & 20.05 & 443 \\
\hline & \multirow[t]{4}{*}{6} & 4 & 2.31 & 286 & 0.81 & 34.6 & 19.72 & 455 \\
\hline & & 5 & 1.79 & 337 & 0.64 & 34.2 & 19.67 & 352 \\
\hline & & 6 & 1.74 & 374 & 0.58 & 33.6 & 19.64 & 342 \\
\hline & & 7 & 1.67 & 418 & 0.50 & 33.1 & 19.61 & 327 \\
\hline
\end{tabular}

Of the factors studied, the greatest importance for the yield was the depth of seed placement and background nutrition. The greatest yield of Runo spelt wheat was provided by seed planting on $4 \mathrm{~cm}$ on both feeding backgrounds. As the depth of seed placement increased, grain collection per unit area decreased. At the same rate of sowing (4 million) on both feeding backgrounds, the seed placement reduced the grain yield by $6 \mathrm{~cm}$ in 
comparison with the placement depth by $4 \mathrm{~cm}$ by $0.15-$ 0.24 tons per 1 hectare.

Application of calculated norms of fertilizers for 3 tons of grain per hectare on all variants of the depth of planting and norms of sowing of seeds contributed to improvement of technological properties of Runo spelt wheat grain (Table 1). protein content in grain increased in relation to natural background at seed planting by 4 $\mathrm{cm}$ at norm of sowing of 4 million germinated grains per hectare by $4.91 \%$ and made $20.18 \%$. Protein harvesting increased by $220 \mathrm{~kg} / \mathrm{ha}$ or $74.5 \%$.

The mass of 1000 grains according to the above mentioned variants of experience increased by $1.8 \mathrm{~g}$.

On both feeding backgrounds, regardless of the depth of seeding, a decrease in the weight of 1000 grains was observed as the sowing rate increased.

Influence of sharp differences from seed placement depth in the interval from 2 to $6 \mathrm{~cm}$ on technological properties of spelt wheat grain was not fixed.

Statistical processing and analysis of experimental data for an average of three years were carried out by the method of main components.

This method allowed to reduce the dimension of the data to two generalized factors - the main components of GK1 and GK2. In the natural background, the dispersion share of the first main component was $68.9 \%$, the second component $-21.8 \%$. In the presence of the nutrition background, the share of $\mathrm{HC} 1$ was $59.1 \%$, the share of HC2 - 27.1\%. Therefore, the first two main components together explain $90.7 \%$ and $86.2 \%$.

Initial load factors within these two main components are presented in Table 2.

Contributions of factors are determined by absolute values of coefficients. It is easy to notice that GK1 is most influenced by the norm of sowing, weight of grain per plant, number of plants before harvesting and weight of 1000 grains. GK2 is mainly influenced by the depth of seeding of seeds.

Table 2. Load factors

\begin{tabular}{|l|c|c|c|c|}
\hline & \multicolumn{2}{|c|}{$\begin{array}{c}\text { Natural background } \\
\text { (no fertilizer) control }\end{array}$} & \multicolumn{2}{c|}{$\begin{array}{c}\text { NPK for 3 tons } \\
\text { of grain }\end{array}$} \\
\hline & GK1 & GK2 & GK1 & GK2 \\
\hline Depth of restraint & -0.25 & 0.89 & 0.15 & -0.90 \\
\hline Seed rate & 0.96 & 0.24 & 0.96 & 0.22 \\
\hline $\begin{array}{l}\text { Number of plants } \\
\text { before harvest }\end{array}$ & 0.97 & -0.10 & 0.83 & 0.49 \\
\hline Grain weight per plant & -0.91 & -0.28 & -0.95 & -0.21 \\
\hline Weight 1000 grains & -0.93 & -0.24 & -0.82 & 0.46 \\
\hline Protein content & 0.71 & -0.56 & 0.59 & -0.52 \\
\hline * Yields & -0.49 & -0.67 & -0.68 & 0.29 \\
\hline
\end{tabular}

Figures 1-2 show graphical images of experimental data in the plane of main components of GK1 - GK2. The designations show the values of adjustable factors seeding rate and seeding depth. Letters A, B, C, D indicate sowing rates of $4,5,6$ and 7 million /ha, respectively. Numbers 2, 4 and 6 indicate the seed placement depth in centimetres. In these graphs, the samples were stratified by the placement depths and seeding rates.

Therefore, it is interesting to study the functional dependence of yield on these two factors. Below are the results of two-factor regression analysis.

The following second-order regression equation was obtained in the experiment with fertilizer application.

$$
\begin{aligned}
& Y_{1}=1.9332-0.4172 X_{1}+0.9743 X_{2}+ \\
& +0.0392 X_{1}^{2}-0.0335 X_{1} X_{2}-0.1038 X_{2}^{2}
\end{aligned}
$$

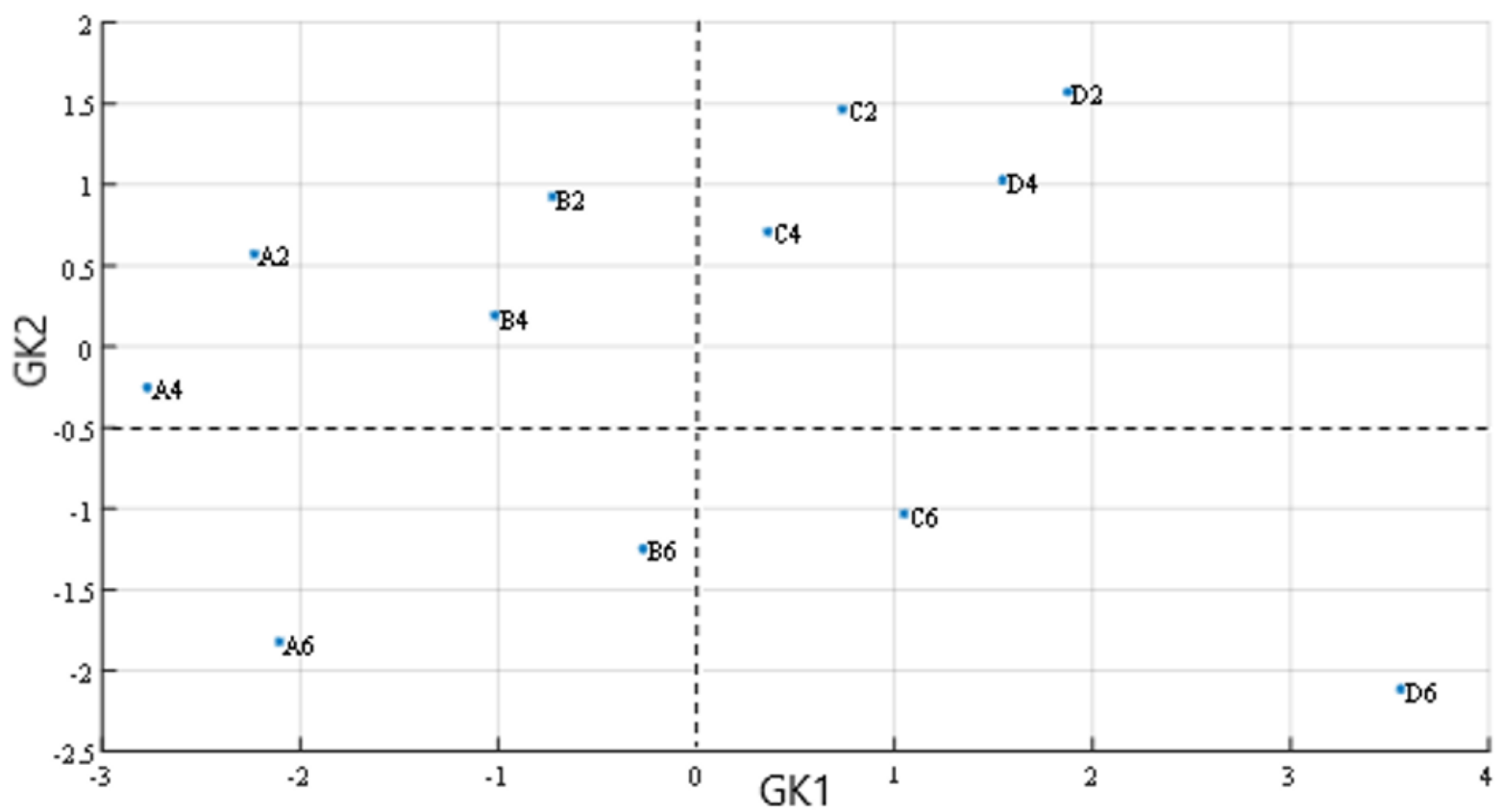

Fig. 1. Schedule of invoices on the variant of calculation of NRK for 3 tons of grain per hectare 


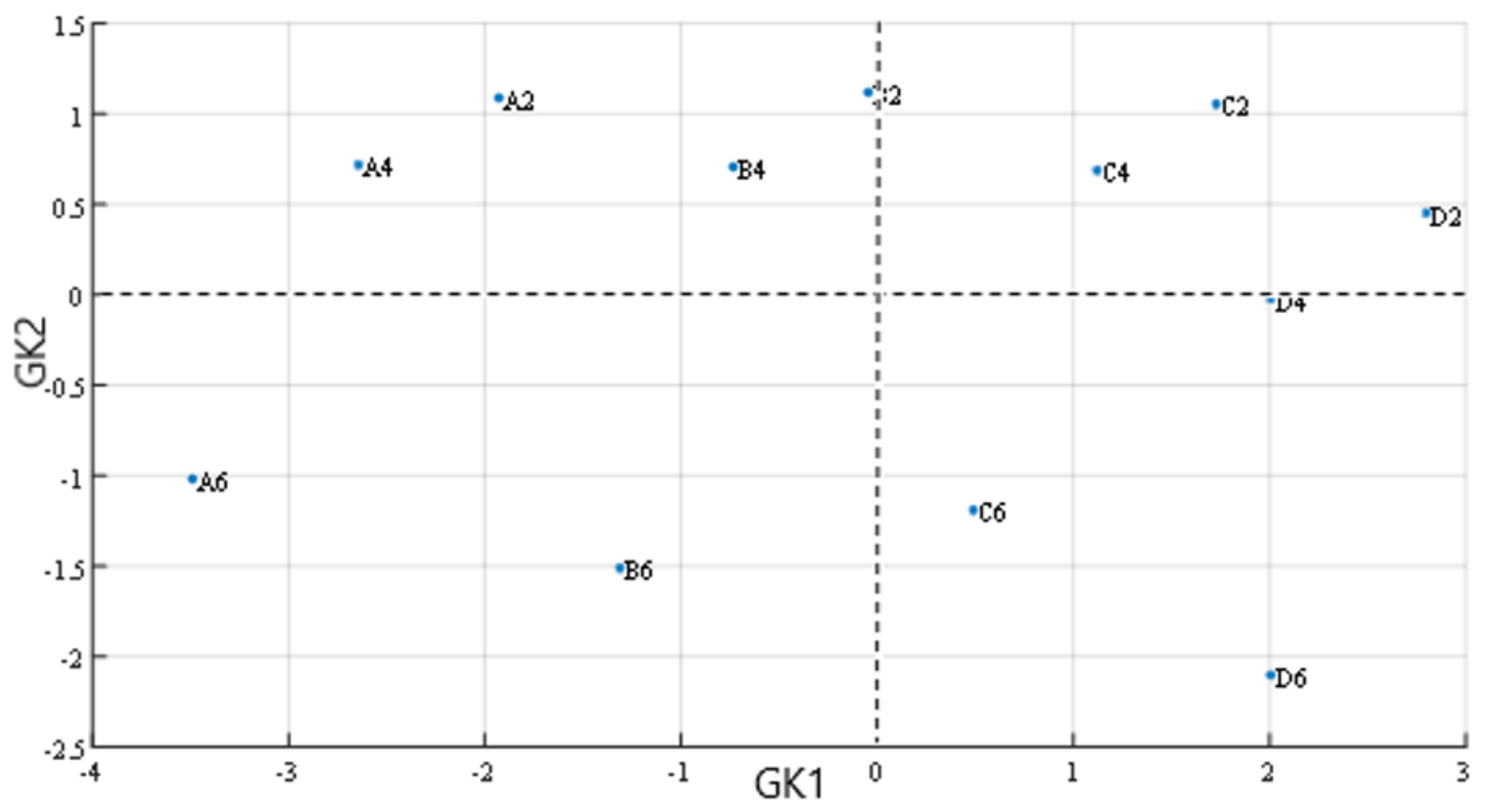

Fig. 2. Chart of accounts on natural background variant

On a natural background (without fertilizer) the regression equation looks like:

$$
\begin{aligned}
& Y_{2}=1.4385-0.0995 X_{1}+0.4553 X_{2}+ \\
& +0.0075 X_{1}^{2}-0.013 X_{1} X_{2}-0.0513 X_{2}^{2}
\end{aligned}
$$

where Y1 - yield with fertilizer application; Y2 - yield without fertilizer application; $\mathrm{X} 1$ - seeding rate; $\mathrm{X} 2$ placement depth.

Figures 3-4 show graphical images of the obtained dependencies in three-dimensional space. The graphs show how the yield has a negative correlation with the factor of sowing rate, with the increase of which the yield decreases.

The sowing depth factor has a more complex structure of interaction with yield. In cases with a large sowing depth, as well as at shallow sowing depth field experiments have shown a decrease in yields.

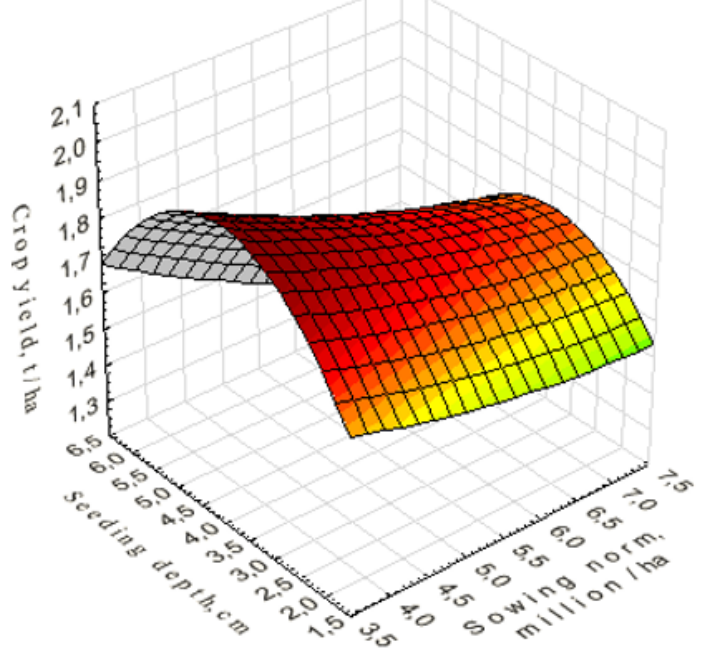

Fig. 3. Grain yield at NRK application per 3 tonnes

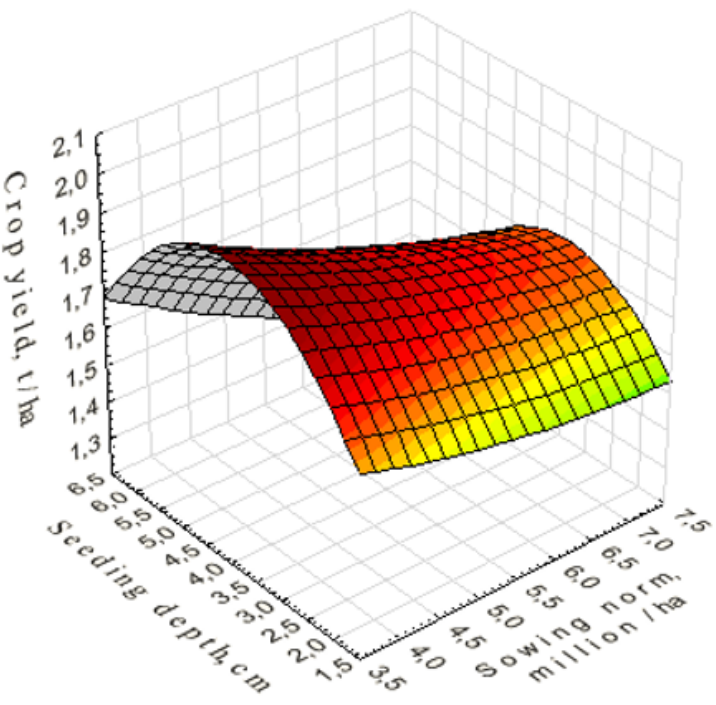

Fig. 4. Grain yield against natural background

Decrease in yield at deep sowing is explained by lack of oxygen in the lower layers of soil, and at shallow sowing depth - by lack of moisture in the upper layers of soil.

Visual study of graphs shows that in each case there is the best sowing depth, which provides maximum yield. In the experience without fertilizer application, the impact of the sowing depth on the yield is less pronounced than in the experience of sowing with fertilizer.

Mathematical models (1) and (2) provide optimal sowing depths.

In case of sowing with fertilizer (model 1), the extreme condition for variable $\mathrm{X} 2$ will be as follows: 


$$
\frac{\partial Y_{1}}{X_{2}}=0.97-0.034 X_{1}-0.207 X_{2}=0
$$

It follows that the best sowing depth with a sowing rate of 4 million/ha is $4.1 \mathrm{~cm}$, with a sowing rate of 5 million/ha $-3.9 \mathrm{~cm}, 6$ million/ha $-3.7 \mathrm{~cm}$, $7 \mathrm{million} / \mathrm{ha}-3.6 \mathrm{~cm}$.

For the model (2) without fertilizer, the extreme condition is:

$$
\frac{\partial Y_{1}}{X_{2}}=0.455-0.013 X_{1}-0.103 X_{2}=0
$$

Then, with a sowing rate of 4 million/ha the optimum depth will be equal to $3.5 \mathrm{~cm}$, with a sowing rate of $5 \mathrm{million} / \mathrm{ha}-3.8 \mathrm{~cm}, 6 \mathrm{million} / \mathrm{ha}-3.7 \mathrm{~cm}$, $5 \mathrm{million} / \mathrm{ha}-3.6 \mathrm{~cm}$.

Thus, the optimal depth of seed placement of spelt wheat for an average of three years on both backgrounds was $4 \mathrm{~cm}$.

The optimum sowing rate, regardless of the background and depth of seeding, was 4 million germinated seeds per hectare.

\section{Conclusion}

The application of the method of principal components made it possible to identify the patterns of influence of the considered factors on crop productivity. Yield of Runo double-grain (spelt) wheat grains highly depends on the seed placement depth and sowing rate. A regression analysis of the dependence of yield on these factors was carried out against a natural background and against a background with the addition of NPK per 3 tons of grain. The optimum seed depth was $3 \mathrm{~cm}$, and the optimum sowing rate was $4 \mathrm{mln}$ germinable seeds per ha.

\section{References}

1. M.F. Amirov, L.G. Sagitov, R.N. Salavatullin, Influence of biological and mineral fertilizers on productivity of spring wheat Grain industry of Russia 2(50), 6-8 (2017)

2. M.F. Amirov, Influence of microelements and mineral fertilizers on yield and quality of spring wheat grain Bulletin of Kazan State Agrarian University 4(47), 5-9 (2017)

3. V.G. Vasin, N.A. Prosandeyev, Technological evaluation of grain and economic efficiency of the herbicides application on wheat and barley sowing News of Orenburg State Agrarian University 3, 5356 (2012)

4. V. Petrenko, T. Sheiko, R. Spychaj, O. Prysiazhniuk, L. Khudolii, Evaluation of three wheat species (Triticum aestivum L., T. spelta L., T. dicoccum (Schrank) Schuebl) commonly used in organic cropping systems, considering selected parameters of technological quality Romanian Agricultural Res. 35, 255-264 (2018)

5. F.Sh. Shaykhutdinov, I.M. Serzhanov, R.I. Ibyatov et al., Influence of the agrotechnical methods on the yield and quality of the spelt wheat grain (two-grain grain) in the conditions of the Ancestral Kama of the Republic of Tatarstan Bulletin of Kazan State Agrarian University 4(51), 103-109 (2018)

6. R.I. Ibyatov, F.Sh. Shaikhutdinov, A.A. Valiev, Yield analysis of spring wheat by the vowel component method Grain industry of Russia 2(50), 17-22 (2017)

7. M.R. Sharafutdinov, L.S. Nizhegorodtseva, R.I. Safin, Methods of prevention of traumatization of spring wheat seeds Grain industry of Russia 2, 6972 (2017)

8. A.N. Kshnikatkina, I.G. Rusyaev, Yield and quality of the spring wheat grain depending on the presowing treatment of seeds with complex fertilizers and bacterial preparations Agrochemical bull. 3, 48-51 (2018)

9. F.N. Safiollin, G.S. Minnullin, M.M. Khismatullin, S.V. Sochneva, Mineral nutrition backgrounds of alfalfa agrocenoses and yield of the following crop of field crop rotation - spring wheat Ekada 70 on gray forest soils of the Republic of Tatarstan Grain economy of Russia 2(50), 20-33 (2017)

10. N. Daskalova, S. Doneva, P. Spetsov, Chromosome variation and HMW glutenins in synthetic hexaploid wheats (Triticum turgidum ssp. dicoccum/Aegilops tauschii) Cereal Research Communications 44(3), 453-460 (2016)

11. I.M. Serzhanov, F.S. Shaykhutdinov, R.I. Ibyatov et al., Runo wheat productivity at different levels of mineral nutrition, seeding rates and seed placement depth in the conditions of the Predkamskaya zone of the Republic of Tatarstan Bulletin of Kazan State Agrarian University 4(47), 63-68 (2017)

12. R.M. Nizamov, R.S. Sagdiev, Sunflower productivity depending on the norms of sowing in the Republic of Tatarstan Bulletin of Kazan State Agrarian University 6, 1(19), 144-146 (2011) 